\title{
A study on correlation between deficiency of vitamin $D$ and knee osteoathritis among patients attending a tertiary care hospital in Andhra Pradesh
}

\author{
Komala Rao, V. Ramesh* \\ Department of Orthopaedics, Great Eastern Medical School and Hospital, Ragolu, Srikakulam, Andhra Pradesh, India
}

Received: 26 August 2020

Accepted: 01 September 2020

*Correspondence:

Dr. V. Ramesh,

E-mail: doctorbone99@gmail.com

Copyright: $\odot$ the author(s), publisher and licensee Medip Academy. This is an open-access article distributed under the terms of the Creative Commons Attribution Non-Commercial License, which permits unrestricted non-commercial use, distribution, and reproduction in any medium, provided the original work is properly cited.

\section{ABSTRACT}

Background: The prevalence of vitamin D deficiency is the burning topic worldwide. Vitamin D deficiency is a under diagnosed medical condition since a significant proportion of the population in many countries and regions around the world have low serum 25-hydroxy $(\mathrm{OH})$ vitamin D levels. The aim of this study was to investigate the association between serum vitamin $\mathrm{D}$ deficiency and knee osteoarthritis $(\mathrm{OA})$.

Methods: The study population consists of 200 patients divided into two groups, group 1 and group 2. Group 1 with 100 subjects with no clinical features of knee osteoarthritis served as controls and group 2 consists of 100 patients of patients diagnosed with knee osteoarthritis. Serum $25-\mathrm{OH}$ vitamin $\mathrm{D}$ was measured in all the participants by the enzymelinked fluorescence assay (ELFA) method and concentrations $<20 \mathrm{ng} / \mathrm{ml}$ was considered as deficient.

Results: In group 1, 47\% were male and 53\% were female whereas in group 2, $41 \%$ were male and $59 \%$ were female. In group 1 , only $8 \%$ are vitamin D deficiency whereas in group 2, 61\% have vitamin D deficiency. There was a significant association between serum vitamin $\mathrm{D}$ and staging of knee OA.

Conclusions: The present study findings showed a significant association between serum $25-\mathrm{OH}$ vitamin D deficiency and in patients with knee OA.

Keywords: Osteoarthritis, Knee joint pain, 25-OH vitamin D, Andhra Pradesh

\section{INTRODUCTION}

Vitamin D deficiency is common, with several epidemiologic studies having demonstrated that low levels of vitamin $\mathrm{D}$ are associated with higher levels of knee pain, increased prevalence of osteoarthritis (OA), as well as development and progression of knee OA. ${ }^{1-4}$ The main function of vitamin $\mathrm{D}$ is to absorb calcium and phosphate: vitamin D deficiency in children leads to rickets, and, in adults, to osteomalacia..$^{5-8}$ In men with vitamin D deficiency, the prevalence of OA has been reported to be significantly higher compared to those with sufficient levels. ${ }^{9}$ Other studies showed that vitamin D deficiency is age-dependent and could be high in elderly patients; these patients are at higher risk of OA in their life. ${ }^{10,11}$ Mild to moderate vitamin D deficiency could be asymptomatic, whereas long-term vitamin D deficiency can cause hypocalcaemia with secondary hyper-parathyroidism and bone mineralization disorder. ${ }^{12-14} \mathrm{OA}$ is the most common form of arthritis. Although OA can affect both spine and peripheral joints, it most commonly occurs in the joints of the hands, neck, waist, knees and pelvis. Existing treatments for OA could reduce disease progression and pain in patients, and improve their joint functions. ${ }^{13-16}$ Many factors such as age, gender, bone deformities or abnormalities, weight, profession and also many underlying diseases such as diabetes, hypothyroidism, gout or Paget's bone disease could increase the risk of OA. ${ }^{17-19}$ The pathogenesis of OA is still unclear. Recent 
studies on changes in sub-chondral bone remodeling phases of bone absorption and of bone sclerosis may be responsible for the cartilage damage..$^{20,21}$ The reason behind these changes in the cartilage and bone is that low levels of 25-hydroxy $(\mathrm{OH})$ vitamin $\mathrm{D}$.

Knowledge of the serum status of 25-OH vitamin D may provide additional information to recognize patients at risk for progression of OA knee. The objective of this study is to evaluate the serum $25-\mathrm{OH}$ vitamin $\mathrm{D}$ status in patients with knee OA scheduled for joint replacement along with healthy individuals for comparison. And also to find out association between serum $25-\mathrm{OH}$ vitamin D levels with age and body mass index (BMI) and with the knee OA.

\section{METHODS}

\section{Study setting and design}

This is a case-control study conducted at the Department of Orthopedics, Great Eastern Medical School and Hospital, Srikakulam, Andhra Pradesh during November 2018 to November 2019. The study was approved by the institutional ethics committee. An informed consent was obtained from all the participants after explaining the purpose of the study.

The study consists of 100 ages matched controls (group 1) and 100 patients with knee osteoarthritis as cases (group $2)$. Further study the subjects were divided into two sub groups based on age ( $<60$ years and $>60$ years) in both group 1 and group 2. Based on BMI, there are four subgroups i.e., BMI <20, 20-25, 26-30 and >30 in each group. Based on vitamin D status there are three subgroups in each group. American College of Rheumatology classification was considered as standard for the diagnosis of knee osteoarthritis.

\section{Inclusion criteria}

Patients who are presented with knee joint pain with clinical and radiological findings. Subjects of the control group were selected over the same period patients without non skeletal symptoms and had no clinical features of knee OA based on history and clinical examination.

\section{Exclusion criteria}

Stage 4 Kelegren-Lawrence stage, severe radiographic knee OA, and those with knee joint instabilities. Patients with physical disabilities, patients with history of rheumatic diseases other than osteoarthritis, chronic kidney diseases, gastrointestinal disorders, pulmonary systems, and persons on anticonvulsant drugs were excluded from the study.

\section{Sampling and data collection}

Demographic information such as age, gender, height, weight, place of residence, history of smoking, education level, and history of arthritis were collected from the participants. Radiographs were done in two posterior anterior and lateral views of the knees with radiographic apparatus (Shimadzu Diagnostic Radiography RAD speed series D digital).

The Kellgren-Lawrence grading system is a radiological classification of knee OA. It ranges from grade 0 to grade 4, and is based on X-ray findings. Radiographs were reviewed and divided into the following stages- grade 1: doubtful narrowing of joint space and possible osteophytic lipping, grade 2: definite osteophytes, definite narrowing of joint space, grade 3: moderate multiple osteophytes, definite narrowing of joints space, some sclerosis and possible deformity of bone contour, and grade 4: large osteophytes, marked narrowing of joint space, severe sclerosis and definite deformity of bone contour.

Venous blood samples were obtained from both groups and serum $25-\mathrm{OH}$ vitamin $\mathrm{D}$ levels were also measured in the laboratory by radioimmunoassay. Serum 25-OH vitamin D level $30 \mathrm{ng} / \mathrm{ml}$ and above was defined as normal, 20-29 ng/ml was considered scant, and $20 \mathrm{ng} / \mathrm{ml}$ and lower indicated deficiency.

\section{Statistical analysis}

The recorded data was compiled and entered in a spreadsheet computer program (Microsoft Excel 2007) and then exported to data editor page of Statistical Package for the Social Sciences version 20 (SPSS Inc., Chicago, Illinois, USA). Descriptive statistics included computation of percentages, means and standard deviations.

\section{RESULTS}

A total of 200 patients recruited for the study. Study population was divided into two groups: group 1 (controls) and group 2 (OA cases). Group 1 includes 100 patients without the clinical symptoms of knee OA and group 2 consists of 100 knee OA. In group 1, 47\% were male and $53 \%$ were female whereas in group $2,41 \%$ were male and $59 \%$ were female.

In both group 1 and group 2, more than $50 \%$ were above 60 years. More than 50\% of them are with BMI of 26-30 and above. Most of our study population are daily wage workers (Table 1).

In group 1 , only $8 \%$ are vitamin $\mathrm{D}$ deficiency whereas in group 2, 61\% have vitamin D deficiency (Table 2).

In Table 3, comparisons of age, BMI, and 25-OH vitamin $\mathrm{D}$ status in controls and OA patients are shown. There is no statistical difference with respect to age of the patients in the both the groups. But, statistical significant difference was observed with respect to BMI and serum 25-OH vitamin D in both control group (group 1) and OA group (group 2) (Table 3). 
Table 1: Characteristics of study population.

\begin{tabular}{|c|c|c|c|c|}
\hline \multirow{2}{*}{\multicolumn{3}{|c|}{ Variables }} & Group 1 (controls) & Group 2 (cases) \\
\hline & & & $\mathbf{N}(\%)$ & $\mathbf{N}(\%)$ \\
\hline \multirow{2}{*}{ Sex } & \multicolumn{2}{|l|}{ Male } & $47(47)$ & $41(41)$ \\
\hline & \multicolumn{2}{|c|}{ Female } & $53(53)$ & $59(59)$ \\
\hline \multirow{4}{*}{ Age (years) } & \multirow{2}{*}{$<60$} & Male & $21(21)$ & $24(24)$ \\
\hline & & Female & $28(28)$ & $25(25)$ \\
\hline & \multirow{2}{*}{$>60$} & Male & $29(29)$ & $25(25)$ \\
\hline & & Female & $32(32)$ & $31(31)$ \\
\hline \multirow{4}{*}{ BMI $\left(\mathrm{kg} / \mathrm{m}^{2}\right)$} & \multicolumn{2}{|l|}{$<20$} & $1(1)$ & $3(3)$ \\
\hline & \multicolumn{2}{|l|}{$20-25$} & $22(22)$ & $18(18)$ \\
\hline & \multicolumn{2}{|l|}{$26-30$} & $49(49)$ & $52(52)$ \\
\hline & \multicolumn{2}{|c|}{$>30$} & $28(28)$ & $26(26)$ \\
\hline \multirow{3}{*}{ Profession } & \multicolumn{2}{|c|}{ Salaried employee } & $15(15)$ & $12(12)$ \\
\hline & \multicolumn{2}{|c|}{ Daily wage worker } & $68(68)$ & $72(72)$ \\
\hline & \multicolumn{2}{|c|}{ Not working } & $17(17)$ & $16(16)$ \\
\hline
\end{tabular}

Table 2: 25-OH vitamin D status in controls and OA patients.

\begin{tabular}{|lll|}
\hline Vitamin D status & $\begin{array}{l}\text { Group 1 } \\
\text { (controls) }\end{array}$ & $\begin{array}{l}\text { Group 2 } \\
\text { (OA cases) }\end{array}$ \\
\hline N (\%) & N (\%) \\
\hline Normal (>30 ng/ml) & $68(68)$ & $16(16)$ \\
\hline Insufficient $(\mathbf{2 0 - 2 9} \mathbf{~ n g / m l ) ~}$ & $24(24)$ & $23(23)$ \\
\hline Deficient $(<\mathbf{2 0} \mathbf{~ n g / m l ) ~}$ & $8(8)$ & $61(61)$ \\
\hline
\end{tabular}

Table 3: Comparison of age, BMI and 25-OH vitamin $D$ status in controls and $O A$ patients.

\begin{tabular}{|lll|} 
Variables & $\begin{array}{l}\text { Group 1 } \\
\text { (controls) }\end{array}$ & $\begin{array}{l}\text { Group 2 } \\
\text { (OA cases) }\end{array}$ \\
\hline Age (in years) & $56.8 \pm 9.2$ & $58.4 \pm 9.6$ \\
\hline BMI & $25.2 \pm 8.1$ & $28.6 \pm 7.2$ \\
\hline 25-OH vitamin D & $40.2 \pm 14.8$ & $35.2 \pm 10.8$ \\
\hline
\end{tabular}

Table 4: Association between 25-OH vitamin D level and stage of the disease.

\begin{tabular}{|l|lll|}
\hline $\begin{array}{l}\text { Vitamin D } \\
\text { level }(\mathrm{ng} / \mathrm{ml})\end{array}$ & \multicolumn{2}{l}{ Stage of the disease } \\
\cline { 2 - 4 } & Grade 1 & Grade 2 & Grade 3 \\
\hline $\mathbf{2 0}$ & $3(\%)$ & $\mathbf{N ~ ( \% )}$ & $\mathbf{N}(\%)$ \\
\hline $\mathbf{2 0 - 2 9}$ & $5(5)$ & $26(26)$ & $32(32)$ \\
\hline$>\mathbf{3 0}$ & $6(6)$ & $8(8)$ & $2(2)$ \\
\hline
\end{tabular}

In patients with knee OA according to Kellgren-Lawrence criteria, $14(14 \%)$ patients were in grade 1, $44(44 \%)$ in grade 2, $42(42 \%)$ in grade 3 (Table 4$)$. There was a significant association between serum vitamin $\mathrm{D}$ and staging of knee OA.

\section{DISCUSSION}

Early structural changes in the joints such as defects in cartilage, decrease in volume of cartilage, expansion of subchondral bone, and lesions in bone marrow will appear before the onset of clinical symptoms of OA. Reports and observations from earlier studies provided a rationale for the measurement of serum $25-\mathrm{OH}$ vitamin D levels with appearance of knee OA in elderly people and encourage supplementation to raise the serum vitamin D concentration to adequate levels. ${ }^{21,23-26}$ Epidemiological studies showed an association between dietary intake and serum levels of 25-OH vitamin D and the progression of hip and knee OA. ${ }^{20,21,23}$ In a recent study, decreased serum level of 25-OH vitamin D was reported in a significant proportion of patients with OA of hip and knee joints. ${ }^{21,23-}$ ${ }^{26}$ All these epidemiological suggests that by achieving normal serum vitamin D level may prevent or delay loss of cartilage loss and reduce the pain and other symptoms of OA. ${ }^{23-25}$ Observation from studies on knee osteoarthritis evaluated by $\mathrm{Cao}$ et al suggested that serum $25-\mathrm{OH}$ vitamin D level play an important role in structural changes of knee OA. ${ }^{25}$

The most important finding of this study is the high prevalence $(61 \%$ deficiency and $23 \%$ insufficiency; around $84 \%$ ) of low serum levels of $25-\mathrm{OH}$ vitamin D in a population with OA, in a sunny region like south India of Asian country.

The main finding of this study is the association between the grade of knee OA and vitamin D levels. Our observations concur with those of Bergink et al who showed that low vitamin D intake increases the risk of radiographic progression of knee OA, especially when the patient's bone mineral density (BMD) is low. Therefore, improving vitamin $\mathrm{D}$ levels in patients may have a protective role against the development of OA, especially in those patients with low BMD. ${ }^{4}$ Similarly, Mc Alindon et al demonstrated significant relationship between serum vitamin D level and progression of OA, so that those with more advanced OA had lower vitamin D levels. ${ }^{3}$ In a study by Muraki et al no significant relationship was found between vitamin $\mathrm{D}$ levels and radiographic $\mathrm{OA}$ of the 
knee, but low levels of $25-\mathrm{OH}$ vitamin D were more associated with knee pain. ${ }^{22}$

Keeping the limitations of earlier studies in view, present study was planned and executed effective to obtain results which are not affected by seasonal variation, diet, and exposure to sunlight or less physical activity due to pain and other confounders because patients and control population recruited for this study were selected from the same geographic territory who had unique racial and cultural backgrounds, with similar diet and sunlight exposure.

\section{CONCLUSION}

It can be concluded that there is a significant association between knee osteoarthritis and vitamin $\mathrm{D}$ deficiency when compared to control population with respect age, gender and BMI. Results showed that there was a significant association between knee OA grade based on Kellgren-Lawrence criteria and serum vitamin D levels. Therefore, identification of high risk subjects and correction of risk factors such as low level serum $25-\mathrm{OH}$ vitamin $\mathrm{D}$ is expected to give beneficial effects, increase in bone mineral density and even decreases fracture risk in the elderly population.

\section{Funding: No funding sources \\ Conflict of interest: None declared \\ Ethical approval: The study was approved by the institutional ethics committee}

\section{REFERENCES}

1. Heidari B, Heidari P, Hajian-Tilaki K. Association between serum vitamin D deficiency and knee osteoarthritis. Int Orthop. 2011;35(11):1627-31.

2. Enteshari-Moghaddam A, Azami A, Isazadehfar KH, Mohebbi H, Habibzadeh A, Jahanpanah P. Efficacy of duloxetine and gabapentin in pain reduction in patients with knee osteoarthritis. Clin Rheumatol. 2019;38:2873-80.

3. McAlindon T, LaValley M, Schneider E, Nuite M, Lee JY, Price LL, et al. Effect of vitamin D supplementation on progression of knee pain and cartilage volume loss in patients with symptomatic osteoarthritis: a randomized controlled trial. JAMA. 2013;309(2):155-62.

4. Bergink AP, Uitterlinden AG, Van Leeuwen JP, Buurman CJ, Hofman A, Verhaar JA, et al. Vitamin D status, bone mineral density, and the development of radiographic osteoarthritis of the knee: The Rotterdam Study. J Clin Rheumatol. 2009;15(5):2307.

5. Glover TL, Goodin BR, King CD, Sibille KT, Herbert MS, Sotolongo AS, et al. A Cross-Sectional Examination of Vitamin D, Obesity, and Measures of Pain and Function in Middle-aged and Older Adults With Knee Osteoarthritis. Clin J Pain. 2015;31(12):1060.
6. Mabey $\mathrm{T}$, Honsawek S. Role of vitamin $\mathrm{D}$ in osteoarthritis: molecular, cellular, and clinical perspectives. Int J Endocrinol. 2015;31(2):118-24.

7. Zoë Miller. 14 foods that contain a surprising amount of vitamin D. 2018. Available at: https://www.insider.com/foods-rich-in-vitamin-d2018-12. Dec 2018. Accessed on: 15 March 2020.

8. Zhang FF, Driban JB, Lo GH, Price LL, Booth S, Eaton CB, et al. Vitamin D Deficiency Is Associated with Progression of Knee Osteoarthritis. J Nutr. 2014;144(12):2002-8.

9. Chaganti RK, Parimi N, Cawthon P, Dam TL, Nevitt MC, Lane NE. Association of 25-hydroxyvitamin D with prevalent osteoarthritis of the hip in elderly men: the osteoporotic fractures in men study. Arthritis Rheum. 2010;62:511-4.

10. Enteshari-Moghaddam A, Isazadehfar KH, Habibzadeh A, Hemmati M. Efficacy of Methotrexate on Pain Severity Reduction and Improvement of Quality of Life in Patients with Moderate to Severe Knee Osteoarthritis. Anesth Pain Med. 2019;9(3):e89990.

11. Mäkinen TJ, Alm JJ, Laine H, Svedström E, Aro HT. The incidence of osteopenia and osteoporosis in women with hip osteoarthritis scheduled for cementless total joint replacement. Bone. 2007;40:1041-7.

12. Antony B, Zheng S, Burgess J, Ding C. Long-term effects of vitamin d supplementation and maintaining vitamin d sufficiency on knee osteoarthritis over 5 years. Osteoarthritis Cartilage. 2018;26(1):S302-3.

13. Dhaon P, Das SK, Srivastava R, Asthana A, Agarwal G. Osteoporosis in postmenopausal females with primary knee osteoarthritis in a vitamin D deficient population. J Assoc Physicians India. 2017;65(11):26-9.

14. Levinger P, Begg R, Sanders KM, Nagano H, Downie C, Petersen A, et al. The effect of vitamin D status on pain, lower limb strength and knee function during balance recovery in people with knee osteoarthritis: an exploratory study. Arch Osteoporos. 2017;12(1):83.

15. Muraki S, Dennison E, Jameson K, Boucher BJ, Akune T, Yoshimura N, et al. Association of vitamin $\mathrm{D}$ status with knee pain and radiographic knee osteoarthritis. Osteoarthritis Cartilage. 2011;19(11):1301-6.

16. Nawabi DH, Chin KF, Keen RW, Haddad FS. Vitamin D deficiency in patients with osteoarthritis undergoing total hip replacement: a cause for concern. J Bone Joint Surg Br. 2010;92(4):496-9.

17. Baskan BM, Yurdakul FG, Aydin E, Sivas F, Bodur H. Effect of Vitamin D levels on radiographic knee osteoarthritis and functional status. Turk J Phys Med Rehabil. 2018;64(1):1-8.

18. Momoeda M, Kaneko H, Liu L, Hada S, Arita H, Aoki T, et al. Vitamin D status is associated with mineralization of osteophyte in patients with knee osteoarthritis. Osteoarthritis Cartilage. 2018;26:5834. 
19. Garfinkel RJ, Dilisio MF, Agrawal DK. Vitamin D and its effects on articular cartilage and osteoarthritis. Orthop J Sports Med. 2017;5(6):232-41.

20. Ross AC, Manson JE, Abrams SA, Aloia JF, Brannon PM, Clinton SK et al. The 2011 report on dietary reference intakes for calcium and vitamin D from the Institute of Medicine: what clinicians need to know. J Clin Endocrinol Metab. 2011;96:53-8.

21. Altman R, Asch E, Bloch D, Boil G, Borestein D, Brandt K, Cheristy W, Cooke TD, Greenwald R, Hochberg $\mathrm{M}$ et al. Development of criteria for classification and reporting of osteoarthritis of the knee. Arthtitis Rheum. 1986;29:1039-49.

22. Muraki S, Dennison E, Jameson K, Boucher BJ, Akune T, Yoshimura N, et al. Association of vitamin $\mathrm{D}$ status with knee pain and radiographic knee osteoarthritis. Osteoarthritis Cartilage. 2011;19(11):1301-6.

23. Goula T, Kouskoukis A, Drosos G, AS, Ververidis A, Valkanis C, Zisimopoulos A, Kazakos K. Vitamin $\mathrm{D}$ status in patients with knee or hip osteoarthritis in a Mediterranean country. J Orthopaed Traumatol. 2015;16:35-9.

24. Heidari B, Heidari P, Tilaki KH. Association between serum vitamin D deficiency and knee osteoarthritis. International Orthopaed (SICOT). 2011;35:1627-31.

25. Cao Y, Winzenberg T, Nguo K, Lin J, Jones G, Ding C. Association between serum levels of 25hydroxyvitamin $\mathrm{D}$ and osteoarthritis: a systematic review. Rheumatol (Oxford). 2013;52:1323-34.

26. Breijawi N, Eckardt A, Pitton MB, Hoelzl AJ, Giesa $\mathrm{M}$, von Stechow D, Haid F, Drees P. Bone mineral density and vitamin D status in female and male patients with osteoarthritis of the knee or hip. Eur Surg Res. 2009;42(1):1-10.

Cite this article as: Rao K, Ramesh V. A study on correlation between deficiency of vitamin $\mathrm{D}$ and knee osteoathritis among patients attending a tertiary care hospital in Andhra Pradesh. Int J Res Orthop 2020;6:1161-5. 